\title{
ISOLATION AND IDENTIFICATION OF GRAM NEGATIVE OXIDASE POSITIVE BACILLI ISOLATED FROM BROILER CHICKENS
}

\author{
WALID H. HASSAN ${ }^{1}$, AHMED H. ABED ${ }^{1}$, SOADABD-EL AZIZ ABD-ALWANIS ${ }^{2}$ and \\ MARWA AHMED YAHIA AL-SAYED ${ }^{3}$
}

\author{
${ }^{1}$ Bacteriology, Mycology and Immunology Department, Faculty of Veterinary Medicine, Beni-Suef University, Beni-Suef \\ 62551, Egypt \\ ${ }^{2}$ Animal Health Research Institute Dokki, Egypt \\ ${ }^{3}$ Animal Health Research Institute Beni-Suef, Egypt
}

Received: 28 August 2017; $\quad$ Accepted: 25 September 2017

\begin{abstract}
Miscellaneous Gram negative bacteria are seriously affecting broiler chickens and poultry industry in Egypt. The present study aimed to isolate and completely identify oxidase positive Gram negative bacterial pathogens recovered from different pathological lesions in broiler chickens by conventional biochemical tests, API20NE and microbact24e system. Samples were taken from 200 Hubbard and Ross broiler chickens of different ages (35weeks), from different farms in Beni-Suef and El-Fayoum Governorates during the period from January 2016 to April 2016. Bacteriological examination showed that Gram negative bacteria were $165(82.5 \%)$ of isolates of which 105 isolates $(52.5 \%)$ were oxidase positive while 60 isolates $(30 \%)$ were oxidase negative. The most prevalent bacterial isolates were Pseudomonas aeruginosa (43 isolates), Aeromonas hydrophila (35 isolates), Pasteurella gallicida (12 isolates), Plesiomonas shigelloides (10 isolates), and Vibrio vulnificus (5 isolates) with incidences of $21.5 \%, 17.5 \%, 6 \% 5 \%$, and $2.5 \%$, respectively.
\end{abstract}

Key words: Gram negative, oxidase positive, broiler chickens.

\section{INTRODUCTION}

Poultry are regarded without any doubt the most appropriate source of protein supply of high nutritive value for man. This is due to efficiency cost of production and its short life cycle. Starting from this point much interest oriented toward maximizing the factors increasing the conversion rate and weight gain as genetic improvement and selection, nutrition balance, and management control, besides minimizing factors inversely affecting conversion rate as diseases and stress factors. Among factors inversely affecting poultry production are diseases and infections (De Haan et al., 2001 and McKissick, 2006).

Pseudomonas aeruginosa ( $P$. aeruginosa) is the most predominant Pseudomonas species causing infection, mortality among birds and clinical signs including septicemia, diarrhea and respiratory signs (ElShafii, 1992 and Tanios and Kamel, 1999).

Corresponding author: Dr. Marwa Ahmed Yahia Al-Sayed E-mail address: ehabram@yahoo.com

Present address: Animal Health Research Institute Beni-Suef, Egypt
Pasteurella multocida is the causative agent of numerous, economically important diseases, including avian fowl cholera and other disorders (De Alwis, 1992). Fowl cholera is a serious disease of poultry and can present in either acute or chronic forms. Obvious clinical signs of acute fowl cholera may not occur until very late in the infection and include depression, ruffled feathers, fever, anorexia, mucous discharge from the mouth, diarrhoea and an increased respiratory rate (Rhoades and Rimler, 1989).

Aeromonas infections in poultry have been reported in different parts of the world with devastating effects (Dashe et al., 2013). A higher occurrence of Aeromonas from chicken source suggests that chicken could be a potential host for the spread of Aeromonas infection and present a possible threat to public health due to the ubiquitous nature of Aeromonas in aquatic, clinical and environmental sources (Smita and Brahmabhatt, 2011).

Plesiomonas shigelloides (previously Aeromonas shigelloides) are ubiquitous, facultative anaerobic, flagellated, Gram-negative rods (San Joaquin, 1994). $P$. shigelloides have been isolated from a variety of environmental sources (Jeppesen, 1995). 
The genus Vibrio includes several food-borne pathogens that cause a spectrum of clinical conditions including septicemia, cholera and milder forms of gastroenteritis. Several Vibrio species are commonly associated with food-borne transmission including $V$. cholerae, $V$. parahemolyticus, and $V$. vulnificus (Azwai et al., 2016).

The purpose of this study is to identify the most prevalent Gram negative oxidase positive bacilli affecting broilers.

\section{MATERIALS AND METHODS}

\subsection{Samples}

Samples were taken from 200 Hubbard and Ross broiler chickens of different ages (3-5weeks), from different farms in Beni-Suef and El-Fayoum Governorates during the period from January 2016 to April 2016.

These chickens were suffered from respiratory manifestations (coughing, sneezing, ralling, nasal discharge and some times swelling of infra orbital sinuses eitherbilateral or unilateral). The chickens were subjected to clinical, postmortem and bacteriological examination of the affected tissues including liver $(n=95)$, kidney $(n=50)$, pericardium $(n=29)$ and air sacs $(n=26)$.

\subsection{Bacteriological examination}

The collected samples were cultivated under aseptic conditionin to Tryptone Soya broth. All inoculated media were incubated aerobically at $37^{\circ} \mathrm{C}$ for $24 \mathrm{hrs}$. Then loopful from the inoculated broth were streaked onto MacConkey's agar, tryptone soya agar (TSA) and dextrose starch agar. The colonies were examined for their cultural characters and morphological appearance according to Mahon et al. (2015).

Medium sized colonies from MacConkey's agar and dextrose starch agar were picked up for purification on TSA and incubated aerobically at 37C for 2472hours. Smears from separate colonies and from livers of suspected fowl cholera cases were stained with Gram's and Leishman's stains and examined microscopically. Colonies revealed pure Gram negative bacilli, showing bipolarity from blood film were inoculated onto nutrient slopes.

Foreach plate, one single colony representing typical colonial appearance and morphological character was picked up and inoculated into $12 \%$ glycerol broth then kept at $-20^{\circ} \mathrm{C}$ for further investigation.

All the recovered Gram negative, medium size and non sporulated isolates (with Gram's stain smears) were further examined biochemically.

\subsection{Biochemical identification of the obtained} bacterial isolates.

\subsubsection{By using conventional biochemical tests.}

The following tests were adapted for identification of bacterial isolates: oxidase, TSI, indole production, methyl red (MR), Voges Prauskeur (VP), citrate utilization, hydrogen sulphide $\left(\mathrm{H}_{2} \mathrm{~S}\right)$ production on TSI, urease activity, nitrate reduction, gelatin liquefaction and sugar fermentation for glucose, lactose, sucrose, mannose, arabinose, maltose and mannitolaccording to Collee et al. (1996). Other tests such ashaemolysis onto blood agar $(\beta)$, motility, growth at $4^{\circ} \mathrm{C}$, Growth at $42^{\circ} \mathrm{C}$ and pigment production were included.

\subsubsection{Identification by using API kit}

The appropriate API kit (API20NE, Oxoid) was selected.API strips should only be used to identify pure cultures of an unknown organism. Gram stain (plus catalase and oxidase if appropriate) were done before inoculating a test strip. It was used according to the manufacturer's instruction.

\subsubsection{Microbact-24E bacterial identification system}

Is a commercial microsystem simplify the identification of Enterobacteriaceae and common miscellaneous Gram-negative bacilli, including oxidase positive GNBs, consists of dehydrated substrates distributed in the wells of microtitre trays with the Thermo Scientific ${ }^{\mathrm{TM}}$ Oxoid $^{\mathrm{TM}}$ Microbact $^{\mathrm{TM}}$ GNB that Kit is a complete, self-contained biochemical based identification system. It Uses 24 different biochemical tests in microplate format to produce easy-to-read, distinct color reactions, generally following overnight incubation. Interpret using the Thermo Scientific ${ }^{\mathrm{TM}}$ Microbact $^{\mathrm{TM}}$ Identification Package) and this was done according to the manufacturer's instruction.

\section{RESULTS}

\subsection{Prevalence of bacterial isolation from the diseased chickens.}

The results recorded in table (1) showed that out of 200 chickens (aged 3-5 weeks) the total number of recovered isolates were $193(96.5 \%)$. Gram negative bacterial isolates were $165(82.5 \%)$ of which 105 isolates $(52.5 \%)$ were oxidase positive and 60 isolates $(30 \%)$ were oxidase negative. Moreover, 28 isolates (14\%) were Gram positive. On the other hand, 7 samples $(3.5 \%)$ had no bacterial isolation (negative isolation). 
Table 1: Prevalence of bacterial pathogens obtained from diseased chickens:

\begin{tabular}{|c|c|c|c|c|c|c|c|c|c|c|c|c|}
\hline \multirow{4}{*}{$\begin{array}{l}\text { Total No. } \\
\text { of samples }\end{array}$} & \multicolumn{10}{|c|}{ Positive isolation } & \multirow{3}{*}{\multicolumn{2}{|c|}{$\begin{array}{l}\text { Negative } \\
\text { isolation }\end{array}$}} \\
\hline & \multicolumn{6}{|c|}{ Gram negative } & \multirow{2}{*}{\multicolumn{2}{|c|}{$\begin{array}{c}\text { Gram } \\
\text { positive }\end{array}$}} & \multirow{2}{*}{\multicolumn{2}{|c|}{$\begin{array}{c}\text { Total } \\
\text { isolation }\end{array}$}} & & \\
\hline & \multicolumn{2}{|c|}{$\begin{array}{l}\text { Oxidase } \\
\text { positive }\end{array}$} & \multicolumn{2}{|c|}{$\begin{array}{l}\text { Oxidase } \\
\text { negative }\end{array}$} & \multicolumn{2}{|c|}{ Total } & & & & & & \\
\hline & No. & $\%$ & No. & $\%$ & No. & $\%$ & No. & $\%$ & No. & $\%$ & No. & $\%$ \\
\hline 200 & 105 & 52.5 & 60 & 30 & 165 & 82.5 & 28 & 14 & 193 & 96.5 & 7 & 3.5 \\
\hline
\end{tabular}

$\%$ : calculated according to the total number of samples.

3.2. Biochemical identification of oxidase positive Gram negative bacterial isolates.

Identification of oxidase positive Gram negative bacterial isolates using traditional biochemical tests as well as API 20NE and Microbact systems revealed thatthe isolates were identified as Pseudomonas aeruginosa, Aeromonas hydrophila, Pasteurella gallicida, Plesiomonas shigelloides and Vibrio vulnificus.
3.3. Prevalence of oxidase positive Gram negative bacterial isolates recovered from diseased chickens.

From the total collected samples $(n=200)$ the most prevalent bacterial isolates were Pseudomonas aeruginosa (43 isolates), Aeromonas hydrophila (35 isolates), Pasteurella gallicida (12 isolates), Plesiomonas shigelloides (10 isolates), and Vibrio vulnificus (5 isolates) with incidences of $21.5 \%$, $17.5 \%, 6 \% 5 \%$, and $2.5 \%$, respectively (Table2).

Table 2: Prevalence of oxidase positive Gram negative bacterial isolates recovered from diseased chickens.

\begin{tabular}{|c|c|c|}
\hline Bacterial isolates & No. & $\%$ \\
\hline Pseudomonas aeruginosa & 43 & 21.5 \\
\hline Aeromonas hydrophila & 35 & 17.5 \\
\hline Pasteurella gallicida & 12 & 6 \\
\hline Plesiomonas shigelloides & 10 & 5 \\
\hline Vibrio vulnificus & 5 & 2.5 \\
\hline Total & 105 & 52.5 \\
\hline
\end{tabular}

No.: Number of isolates.

$\%$ : was calculated according to the total number of the examined cases.

3.4. Prevalence rates of bacterial pathogens in relation to site of isolation:

The result recorded in table (3) showed that the bacterial pathogens were isolated from samples from liver $(n=56)$, kidney $(n=30)$, pericardium $(n=14)$ and air sac $(n=5) . P$. aeruginosa was isolated from 21 livers, 8 kidneys, 9 pericardia and 5 air sacs with incidence rates of 37.5, 26.7, 64.3 and 100\%, respectively. Aeromonas hydrophila was isolated from 17 livers, 13 kidneys and 5 pericardia with incidence rates of 30.4, 43.3 and $35.7 \%$, respectively. Pasteurella gallicida was mainly isolated from 8 livers and 4 kidneys with incidence rates of 14.3 and $13.3 \%$, respectively.

Plesiomonas shigelloides was mainly isolated from 6 livers, 4 kidneys with incidence rates of 10.7 and $13.3 \%$. Vibrio vulnificus was mainly isolated from 4 livers and one kidney with incidence rates of 7.1, $3.3 \%$ respectively. 
Table 3: Prevalence rates of bacterial pathogens in relation to site of isolation:

\begin{tabular}{|c|c|c|c|c|c|c|c|c|c|c|c|}
\hline \multirow{3}{*}{$\begin{array}{c}\text { Site of } \\
\text { samples }\end{array}$} & \multirow{3}{*}{$\begin{array}{c}\text { No. of } \\
\text { isolates }\end{array}$} & \multicolumn{10}{|c|}{ Bacterial isolates } \\
\hline & & \multicolumn{2}{|c|}{$\begin{array}{c}\text { Pseudomonas } \\
\text { aeruginosa }\end{array}$} & \multicolumn{2}{|c|}{$\begin{array}{c}\text { Aeromonas } \\
\text { hydrophila }\end{array}$} & \multicolumn{2}{|c|}{$\begin{array}{c}\text { Pasteurella } \\
\text { gallicida }\end{array}$} & \multicolumn{2}{|c|}{$\begin{array}{c}\text { Plesiomonass } \\
\text { higelloides }\end{array}$} & \multicolumn{2}{|c|}{$\begin{array}{c}\text { Vibrio } \\
\text { vulnificus }\end{array}$} \\
\hline & & No. & $\%$ & No. & $\%$ & No. & $\%$ & No. & $\%$ & No. & $\%$ \\
\hline Liver & 56 & 21 & 37.5 & 17 & 30.4 & 8 & 14.3 & 6 & 10.7 & 4 & 7.1 \\
\hline kidney & 30 & 8 & 26.7 & 13 & 43.3 & 4 & 13.3 & 4 & 13.3 & 1 & 3.3 \\
\hline Pericardium & 14 & 9 & 64.3 & 5 & 35.7 & - & - & - & - & - & - \\
\hline Air sac & 5 & 5 & 100 & - & - & - & - & - & - & - & - \\
\hline Total & 105 & 43 & 41 & 35 & 33.3 & 12 & 11.4 & 10 & 9.5 & 5 & 4.8 \\
\hline
\end{tabular}

$\%$ : was calculated according to the number (No.) of isolates.

\section{DISCUSSION}

No doubt that many microorganisms are considered to be the most important causative agents infect poultry causing significant economic losses are incurred in commercially produced poultry worldwide due to diseases caused by bacterial agents (Barnes et al., 2003).

Out of 200 examined broiler chickens; with respiratory disorders and kidney lesions by taking samples from liver, kidney, heart blood and air sac. The total number of Gram negative bacterial isolates were 165 while 28 isolates were Gram positive and the remaining 7 cases were bacteriologically negative (3.5\%). Such obtained results are nearly coinciding with that reported by Harbi et al. (1982); Poornima and Upadhyde (1995) and Sedhom (2000). Samples with negative bacterial isolation could be attributed to viral, parasitic or fungal causatives (De Herdt et al., 2008 and Karki et al., 2009).

Results of traditional biochemical tests for bacterial identificationare the same to the results obtained by Macfaddin (1976); Krieg et al. (1984); Sedhom (2000) and Emam (2006).

Concerning using MB24E and API20NE besides conventional biochemical methods for diagnosis; the MB24E identifications were found to be "correct". Thus in their hands, the MB24E gave $100 \%$ correct identification, while the API20E was "correct" to species level in $97.4 \%$ of cases (Mugg and Hill, 1981).

The MB24E gave very similar results to the API20E for the identification of common clinical isolates of both-. Enterobacteriaceae and non-fermenting Gram negative bacilli, and is suitable for use in a routine diagnostic laboratory. The API20E database is more extensive than that of the MB24E and contains more examples of rare organisms. Both systems are more reliable for the identification of clinical rather than environmental isolates (Ling et al., 1988). The most prevalent isolate was $P$. aeruginosa (43 isolates) with a prevalence rate of $21.5 \%$ followed by Aeromonas hydrophila (35 isolates; 17.5\%) then Pasteurella gallicida (12 isolates, 6\%), Plesiomonas shigelloides (10 isolates; 5\%), and Vibrio vulnificus (5 isolates; $2.5 \%)$. Such results are in agreement with that of (El Sayed et al.,b2016) who recovered P. aeruginosa from liver of freshly dead chickens and yolk sac of dead -in-shell embryos 12/100 (12\%) and 26 (52\%) respectively and, the total isolation rate was $38 / 166$ (22.9\%). Enany et al. (1986) recovered 30 isolates of $P$. aeruginosa from 250 diseased broilers in Sharkia. This prevalence was higher when compared with the separate findings of different authors in Egypt, where, Younes et al. (1990); Riad (1994); Abd El-Gawad et al. (1998) Osman et al. (1998); Mahmoud and Moussa (2000) and Mohammed (2005) who reported prevalence of $4.9 \%, 7.4 \%, 8 \%, 9.43 \%, 6.6 \%$ and $9.3 \%$, respectively. This result may be considered low if compared with that reported by Kurkure et al. (2001) who recorded a prevalence of $57 \%$.

Tandomly; Kumar et al. (2000) reported a close prevalence of Aeromonas (16.7\%) in poultry meat while Shinde et al. (2005) observed a moderate prevalence $(24 \%)$ in poultry meat. Alhough, a very high prevalence $(55 \%)$ was found in the studies of Smita et al. (2011). Presence of Aeromonas species in foods of animal origin, water environment and retail foods as evident from the available literatures may indicate that these products can act as possible source of vehicles for dissemination of food-borne Aeromonas gastroenteritis (Neyts et al., 2000; Bhowmik et al., 2009). The Present findings emphasized the need of more intensive study on distribution of Aeromonads in soil, water environment and foods of animal origin considering its public health implications. Hygiene at retail chicken shop where samples were collected was heavily compromised and water use for carcass washing may be important critical point in carcass contamination from wide number of gastrointestinal 
food-borne zoonotic pathogens. It was observed that water kept in bucket for washing either fish or chicken carcass was not subject to frequent change and used for dipping of number subjects.

The isolation rate of Pasteurella gallicida was $6 \%$ (12 isolates,) which was in agreement with that of Mbuthia et al. (2008) who isolated P. multocida from $25.9 \%$ of healthy-looking ducks and $6.2 \%$ of chickens from free-range family poultry farms. Aslightly lower than that recorded by Mohamad et al. (2012) who studied the prevalence of $P$. multocida strains among 275 backyard chickens from different regions of Upper Egypt. A total of 21 isolates P.multocida were recovered in 21 out of 275 chickens tested (7.6\%) and were confirmed using phenotypic characterization. While Varga et al. (2007) determined Pasteurella sp. by using biochemical characterization and PCR-based techniques and also determined lower incidence as $87 \%$ of the isolates belonged to P. multocida. $10 \%$ of the strains were P. multocida subsp. septica. Only $3 \%$ of the isolates were P. multocida subsp. gallicida.

The result recorded in table (3) showed the prevalence rates of bacterial pathogens in relation to site of isolation $P$. aeruginosa was isolated with incidence rates of $37.5,26.7,64.3$ and $100 \%$, respectively. Meanwhile, A. hydrophila was isolated with incidence rates of $30.4,43.3,35.7$ and $0 \%$, respectively. P. gallicida, P.shigelloides and $V$. vulnificus were isolated only from liver and kidney samples. The incidence rates in liver were 14.3, 10.7 and $7.1 \%$, respectively, while incidence rates in kidney were $13.3,13.3$ and $3.3 \%$, respectively.

$P$. aeruginosa was isolated from pericardium, liver, spleen, trachea, nasal discharge, intestinal contents and yolk sac of dead broiler chicks by (Kurkure et al. 2001). They added that it was responsible for early mortality in broiler chicks. Also the isolation of 11 isolates of $A$. hydrophila species from 3 different organs (bone marrow, heart and liver) of clinically sick chickens was an indication that avian species were susceptible to this organism. Despite that Aeromonas species have not been reported as an important poultry pathogen; there are documented reports that the organism caused a fulminating disease which was characterized with high mortality in wildlife birds such as canary birds (Franca et al., 2009). The low frequency of isolation of $A$. hydrophila from tissue samples of clinically sick birds could be due to indiscriminate administration antibiotics to birds by poultry farmers once any sign of disease is observed.

P. multocida was readily isolated, often in pure culture from visceral organs such as lung, liver and spleen, bone marrow, gonads or heart blood of birds that succumb to the acute bacteraemic form of the disease, or from the caseous exudate characteristic of chronic fowl cholera lesions (Curtis et al., 1980 and Snipes et al., 1988).

\section{CONCLUSION}

Fowls are susceptible to numerous infections attributable to many organisms. The present study focusing on oxidase positive Gram negative bacteria: the most prevalent isolates were Pseudomonas aeruginosa (43 isolates), Aeromonas hydrophila (35 isolates), Pasteurella gallicida (12 isolates), Plesiomonas shigelloides (10 isolates), and Vibrio vulnificus (5 isolates) with incidences of $21.5 \%$, $17.5 \%, 6 \% 5 \%$, and $2.5 \%$, respectively.

\section{ACKNOWLEDGEMENT}

I wish to express my high appreciation and sincere thanks to Prof. Dr. Ismail Abd El-Hafeez Radwan, Prof. and head of Bacteriology, Mycology and Immunology Department, Faculty of Veterinary Medicine, Beni-Suef University for his valuable effort, guidance, continuous encouragement all over this work, the completion of this work was impossible without his fruitful effort and support.

\section{REFERENCES}

Abd El-Gawad, A.M.; Aly, S.M and Azzaz, H.A. (1998): Some studies on pseudomonas infections in growing chickens in Assuit farms. Assuit J. Vet. Med., 38: 76.

Azwai, S.M. et al. (2017): "Isolation and Molecular Identification of Vibrio Spp. by Sequencing of $16 \mathrm{~S}$ rDNA from Seafood, Meat and Meat Products in Libya." Open Veterinary Journal 6.1 (2016): 36-43. PMC. Web. 2 Aug.

Barnes, H.J.; Vaillancourt, J.P. and Gross, W.B. (2003): Collibacillosis In: Diseases of poultry, $11^{\text {th }}$ Ed. Y.M.

Bhowmik, P.; Bag, PK.; Hajra, TK.; Sarkar, RP. and Ramamurthy, T. (2009): Pathogenic potential of Aeromonas hydrophila isolated from surface waters in Kolkata, India. J. Med. Microbiol. 58:1549-1558

Collee, J.G.; Miles, R.S. and Watt, B. (1996): Testes for the identification of bacteria J.G. Collee (Ed.), Mackie \& McCartney Practical Medical Microbiology, Churchill Livingstone, New York, USA.

Curtis, P.E.; Ollerhead, G.E. and Ellis, C.E. (1980): Pasteurella multocida infection of poultry farm rats. Vet. Rec., 107: 326-327.

Dashe, Y.G.; Raji, M.A.; Abdu, P.A. and Oladele, B.S. (2013): Aeromonas hydrophila infections in chickens affected by fowl cholera in Jos Metropolis, Nigeria. Int. J. Microbiol. Immunol. Res. 1, 032-036. 
De Alwis MCL (1992): Pasteurellosis in Production Animals: AReview. In: Pasteurellosis in Production Animals, ACIAR Proceedings No. 43 (Patten BE, Spencer TL, Johnson RB, Hoffman D \& Lehane L, eds), pp. 11-18. ACIAR, Bali, Indonesia.

De Haan, C.; Schillhorn van Veen, T.; Brandenburg, B.; Gauthier, J.; Le Gall, F.; Mearnsand, R. and Simeon, M. (2001): livestock development: Implications for Rural Poverty, the Environment, and Global Food Security. The World Bank (Eds.), Washington D.C

De Herdt, P.; Paul, G.; Koopman, R. and Van deZande, S. (2008): Field experiences with ERS type Reo-virus infections in diseased broilers reared under western European field circumstances. Vlaams Diergeneeskundig Tijdschrift; 77(3): 171-175.

Elsayed, MSA.; Ammar, AM.; Al shehri, ZS.; Abd-El Rahman, H. and Abd-El Rahman, NA. (2016): Virulence Repertoire of Pseudomonas aeruginosa from some Poultry Farms with Detection of Resistance to Various Antimicrobials and Plant Extracts. Cell MolBiol 62: 124. doi:

El-shaffi, E.S. (1992): Studies on Pseudomonas infection in poultry in Kaliobia province M. V. Sc. Thesis, (microbial.) Fac. Vet. Med., Zagazig Univ., Egypt

Emam, H.E.F. (2006): Bacteriological and Histopathological studies on $P$. aeruginosa infection in chickens M.V.Sc, Dept Bacteriol, Immunol. \& Mycol Vet. Med. Suez Canal Univ., Egypt.

Enany, M; El-Kenawy, A. and Abd-El- Galil, Y (1986): Study on Pseudomonas aeruginosa infection in Sharkia Govemorate. Zagazig. J. Vet. 14: 104- 111.

Harbi, M.S.M.A.; Mustafa, A.; Salih, M.M. and ElAmin, S.M.M. (1982): Isolation and identification of Mycoplasmas from the respiratory tract of White Leghorn chicken in the Sudan. Brit. Vet. J., 138 (3): 253-257.

Franca, M.; Walker, R.L.; Kokka, R. and Shivaprasad, H.L. (2009): Aeromonas species associated with necrotizing enteritis and septicemia in an adultmale ostrich (Struthiocamelus). Avian Dis., 53: 310-316.

Jeppesen, C. (1995): Media for Aeromonas spp., Plesiomonas shigelloides and Pseudomonas spp. food and environment. Int $\mathrm{J}$ Food Microbiol; 26:25-41.

Karki, K.; Manandhar, P. and Koirala, P. (2009): Clinical laboratory epidemiological investigation of hemorrhagic proventriculitis and gizzard erosion in Nepal. Veterinary World; 2 (2): 54-56.

Krieg, N. and Holt, J., eds. (1984): Bergey's Manual of Systematic Bacteriology. Volume 1. Baltimore: Williams and Wilkins. p. 141-164
Kurkure, N.V.; Kalorey, D.R.; ShubhangiWarkeSakhare, P.S. and Bhandarkar, A.G (2001): Mortality in young broilers due to Pseudomonas aeruginosa. Ind. J. Vet. Res., 10 (1): 55- 57

Kumar, A.; Bacchil, VN.; Bhilegaonkar, KN. and Agarwal, RK. (2000): Occurrence of entoroxigenic Aeromonas species in foods. J. Commun. Dis. 32:169-174

Ling, Hui, French J. (1988): Clin Pathol; 41:910-914 Evaluation of the Microbact-24E bacterialidentification system JULIA M LING, Y-W HUT, G L FRENCH Department of Microbiology, The Chinese University of Hong Kong, The Prince of Wales Hospital, Shatin, New Territories, Hong Kong

Macfaddin, J.E. (1976): Biochemical tests for identification of medical bacteria. The Wilkins Company, Baltimore, USA.

Mahmoud, A.E. and Moussa, H.M. (2000): Studies on some aerobic bacterial diseases in broilers. Egyp. J. Agric. Res., 78: 25-34.

Mahon, C.R.; Lehman, D.C. and Manuselis, G. (2015): Textbook of Diagnostic Microbiology, $5^{\text {th }}$ edition.

Mbuthia, P.G.; Njagi, L.W.; Nyaga, P.N.; Bebora, L.C.; Minga, U.; Kamundia, J. and Olsen, J.E. (2008): Pasteurella multocida in scavenging family chickens and ducks: carrier status, age susceptibility and transmission between species. Avian Pathol. 37: 51-57

McKissick, J.C. (2006): Poultry Industry Outlook. The University of Georgia, Athens, USA.

Mohamed, M.A.; Mohamed, M.W. and Ahmed, A.I. (2012): P. multocida in backyard chickens in Upper Egypt: incidence with polymerase chain87 reaction analysis for capsule type, virulence in chicken embryos and antimicrobial resistance. Vet. Ital. Jan. 48: 7786.

Mohammed, F.A.M. (2005): Some studies on bacterial causes associated with cases of swollen head syndrome in chickens. Assuit J. Vet. Med., 51 (104): 193- 211

Mugg, P. and Hill, A. (1981): Comparison of the Microbact-12E and 24 Esystems and the API$20 \mathrm{E}$ system for the identification of Enterobacteriaceae. J Hyg; 87:287-97

Neyts, K.; Huys, G.; Uyttendaele, M.; Swings, J. and Debevere, J. (2000): Incidence and identification of mesophillic Aeromonasspecies from retail foods. Lett. Appl. Microbiol. 31: 359-363

Osman, K.; Jakeen El- Jakee; Hashad, M. and Nashwa, A. Ezz El- Deen (1998): Biological characterization of Pseudomonas aeruginosa isolated from diseased chickens. Giza J. Vet. Med., 46: 451-461

Poornima, M. and Upadhyde, A.S. (1995): Bacterial flora of respiratory tract of poultry in health 
and disease. Mysore J. Agric. Sci., 29(1): 6872

Rhoades, KR. And Rimler, RB. (1989): Fowl Cholera. In: Pasteurella and Pasteurellosis (Adlam C \& Rutter JM, eds), pp. 95-144. Academic Press Limited, London

Riad, E.M. (1994): Characterization of Pseudomonas species isolated from domestic animals and poultry Ph. D. thesis, (Microbiol.), Fac. Vet. Med., Cairo Univ. Egypt.

San Joaquin, VH. (1994): Aeromonas, Yersinia, and miscellaneous bacterial enteropathogens. Pediatr Ann; 23: 544-8.

Sedhoom, H.A.M. (2000): Microbiological studies on respiratory affections in chickens. M.V.Sc. Thesis, (Microbial.), Fac. Vet. Med., Cairo Univ., Egypt.

Shinde, SV.; Zade, NN.; Kolhe, RP. and Karpe, AG. (2005): Prevalence of multiple drug resistance Aeromonas species from chicken. J. Bombay Vet. Coll. 13:36-39

Smita, Bhong CD. and Brahmbhatt, MN. (2010): Selective culture media for the recovery of
Aeromonas species from poultry meat. Ind. J. Vet. Res. 20:66-68.

Smita, Brahmabhatt, M.N. (2011): Prevalence of Aeromonas species in chicken samples collected from retail shops of Anand (Gujarat). J. Vet. Pub. Health 9, 115-117.

Tanios, A.I. and Kamel, S.M. (1999): Serovars, antibiogram and virulence features of Pseudomonas aeruginosa isolated from chickens. Egypt. J comp. Path., 12(1):1-7

Varga, Z.; Sellyei, B. and Magyar, T. (2007): Phenotypic and genotypic characterization of Pasteurella multocida strains isolated from pigs in Hungary. Veterinary Medical Research Institute of the Hungarian Academy of Sciences. Actavtererinaria Hungarica 55: 42543.

Younes, J.; Youssef, H.; Abdel-Karim, S. and Hossauein, K. (1990): Epidemiological studies of Pseudomonas aeruginosa in chickens, fish and human. Assuit J. Vet. Med., 23(45): 48-56.

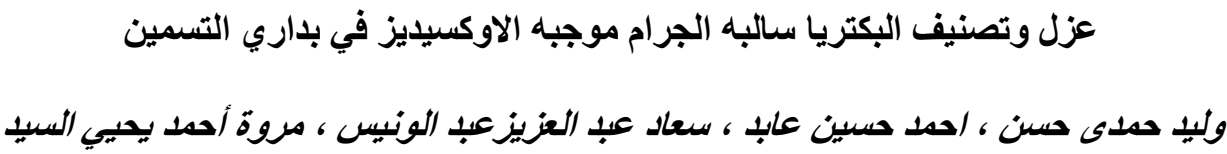

E-mail: ehabram@yahoo.com Assiut University web-site: www.aun.edu.eg

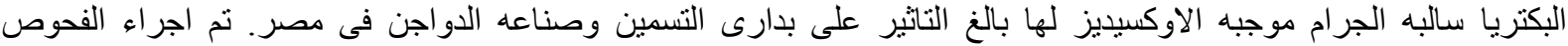

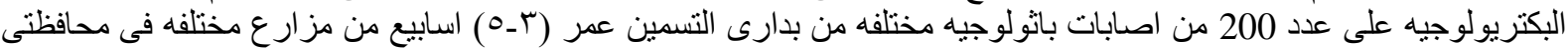

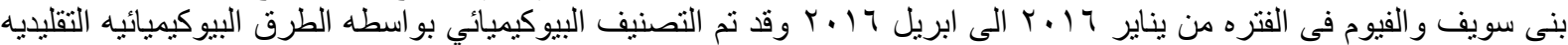

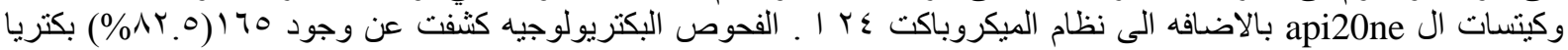

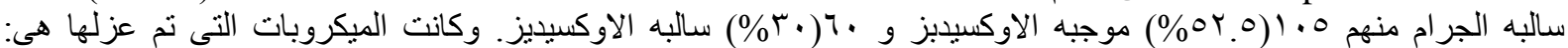

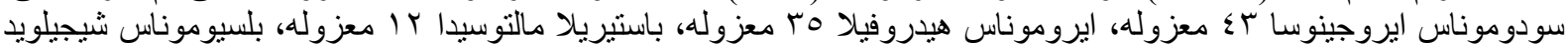

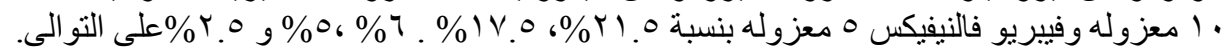

الكلمات المفتاحية : البكتريا سالبه الجر ام - موجبه الاوكسيديز - بداري التسمين. 